\title{
The Borderless-Border and Internal Security Challenges in Nigeria
}

\author{
${ }^{1}$ Osimen, Goddy U, ${ }^{2}$ Anegbode, E. John (Ph.D), ${ }^{1}$ Akande, Clement. A, ${ }^{1}$ Oyewole, \\ Oyindamola O \\ ${ }^{1}$ Department of Political Science \& International Relations Achievers University, Owo \\ ${ }^{2}$ Department of Political Science, Ambrose Alli University, Ekpoma. Edo State
}

\begin{abstract}
The international border between Nigeria and her neighboring countries is roughly $4745 \mathrm{sq} . \mathrm{km}$. The major border countries with Nigeria are Cameroon (1,690 kilometers) in the east, Niger (1,497 kilometers) in the north, Benin (773 kilometers) in the west, and Chad (87 kilometers) in the north-east. Nigeria also shares maritime boundaries with Equatorial Guinea and Sao Tome and Principle. The current border corresponds to the inter-colonial border between British and French territories that was set up in 1889. Due to the fact that between these countries hardly any natural boundaries exist, in some parts its exact demarcation remains unclear. The border region includes a large surface of lagoon-and marshlands in the Ouémé valley, which have traditionally been used as transport and trade routes and which are very difficult to control and monitor by migration and customs authorities. This coupled with the challenges facing African states to manage their borders are compounded by globalization that is tearing down traditional borders through advancement in technology and transformation of international relations. At the moment crimes are committed without crossing borders and huge amounts of goods are sold through cyberspace. The problem of security as a result of these borderless-borders in Nigeria has become one of the most intractable challenges facing the country today. In recent time, the security challenges in Nigeria and its border crime are alarming, especially, the activities of the terrorist group known as 'Boko Haram' in which lives and property are no longer secure. There are many speculations that the groups may have found their way through our porous borders. Therefore, the study probes into the nature of Nigeria borders using analytical framework of assessment in the emerging trans-border crimes, the causes and sources of insecurity of lives and property in Nigeria. The paper then revealed that the major criminal activities in Nigeria borders are smuggling of contraband goods and illegal immigrants, trafficking in weapons and human parts, drug trafficking, vehicle crime, trafficking of illegally exploited natural resources, including the illicit trade in timber, oil and diamond among others. The paper then suggests that much of the conventional wisdom regarding how best to address Nigeria border crime and security is not only enacting a law but also creating proper national security awareness, involvement of new stakeholders in the security sector and strong institutional framework to checkmate the activities of trans-border crime.
\end{abstract}

Keywords: Border, Borderless-Border, Internal Security, Challenges, Nigeria

\section{INTRODUCTION}

The challenges facing African states to manage their borders are compounded by globalization that is tearing down traditional borders through advancement in technology and transformation of international relations. At the moment crimes are committed without crossing borders and huge amounts of goods are sold through cyberspace. The internet has not only made it more difficult to manage borders and to combat cross-border crimes, but has also effectively dismantled borders by allowing imports without going through customs. Trans-border crimes are said to have manifested themselves with the coming of colonialism which regrouped states and communities into new nationstate with defined borders manned by law enforcement agent to protect the polity and its economy. Nigeria is a colonial creation whose final stage was the merge of southern and northern protectorate in 1914. Nigeria came to share international land border with Benin, Niger, Chad and Cameroon, totalling about $4745 \mathrm{sq} . \mathrm{km}$. Nigeria also shares maritime boundaries with Equatorial Guinea and Sao Tome and Principle. Like other partitioned areas in Africa, the territorialisation of Nigeria state poses some challenges that have affected the structure of interregional trade as a result of colonial and postcolonial economic system. Borderlands are both melting pots and security hot spots. Often neglected in the development strategies of postcolonial states, they are an arena for cross-border crime and 
represent a dynamic place of historically fostered cultural and socio-economic exchange at the same time.

However, 'trans-border crime' represent a number of illegal and notorious activities carried out by individuals and group across national and international borders, either for financial or economic benefits and also-political cum religious considerations. It is a set of criminal acts whose perpetrators and repercussions go beyond territorial borders. These would include human. The transfer of criminal activity from one country to another is a spill over effect of interrogation policies which loosen the borders for the purpose of development and enhancing great friendly balance crimes such as human trafficking, arm and drugs are seen to cut across one geographical area but the failure to check and properly control their various activities cause security issues especially the influx of arms around border. Out of the 1978 entry points in the country only 84 are approved and 1894 illegal route lies around the country. Of a true, the security system is greatly outnumbered by an expounded crime situation which in turn will lose it efficacy. (Phil William, 1998).

As organized criminal groups or individuals carry out their illicit activities using major technological tools such as information networks, financial system and other sophisticated means. They also take advantage of difference in legislation, legal systems and traditions, which often seriously hamper state efforts to respond adequately to the threat of organised or trans-border crimes. Ortuno and Wiriyachai (2009) have maintained that, the past few years have been characterized by a significant increase in global criminal activities such as money laundering, trafficking in human and nuclear technology and material, the trade in human organs and migrant smuggling. At the same time, emerging crimes such as modern piracy, trafficking in toxic waste, counterfeit medicines, precious metals or natural resources have been added to the list of traditional illegal activities such as prostitution, drug trafficking and arms trafficking.

Trans border crimes which have been present in Nigeria, became more pronounced in the 1980s and by 1990s, although without much empirical evidence, Nigeria are counted amongst the top ranking global syndicates (Bayard, JF. Et al, 1999:10-11; Williams, P.1998:263-4)'

Most recently, transnational crime has grown in scope and is characterized by increasingly global reach, involved in multiple forms of criminal markets to include large scale financial fraud and cybercrime. And the syndicates are willing to protect their activities through violent and notorious organizational strategies to deter capture (Luna 2008). When borders opened (Trade liberalization), they facilitate the spread of criminals networks. The conditions favourable to crime include: the poverty in source countries and their drive to alleviate that poverty, the weakness of the new democracies, open borders, and lack of appropriately educated law enforcement agencies and a lack of cross-national cooperation has been discovered mostly to be responsible for cross-border crime.

A Study estimates funds involved in global money-laundry and much of with is gained from transnational crimes, at between $2 \%$ and $5 \%$ of world economy output been dollar equivalent of between of $\$ 590$ billion to $\$ 1.5$ trillion (kligman 2004). Also the International Organisation for Migration Estimate (IOME) estimate roughly 700.000 woman and children are trafficked across international borders annually (Binder 2004). This revelation is of no mean implication, particularly post-socialist Eastern Europe where trans-border institution and availability of cheap- labour to wealthier western European countries have become an economic strategy to secure a higher living standard (Hughes, 2004). Justifying the existence a relation between poverty and transnational prostitution, Moldova and Ukraine, two of the prime sources for commercial sex workers, share in gross national income (GNI) of $\$ 460, \$ 770$ respectively, in sharp contrast in two destination countries of Czech republic and Poland with $\$ 5,560$ and $\$ 4770$ respectively (kligman,2004).

Apparently because of the huge financial benefit they attract, transnational organize crime organized criminal enterprises have evolved "extremely complex of organizational structures" that foreclose them from the reach of state security and laws. Chinese Triads, the Columbia Cartels, Japanese Yakuza and the Sicilian are a few of the well known transnational criminal enterprises by government around the world. Several others bodies with home bases in the Caribbean, Central and Eastern Europe West Africa have also received world attention, while a lesser scale evidence of such operations also exists in the UK. Similarly a West East movement of luxury cars theft in Germany and some other western European countries has equally provided trans boarder criminals with vast amount of dirty or illegal money (Gilmore, 1999. P.16). that these Trans border criminal groups conveniently escape national security and laws promulgated to combat their operation is a pointer to the level of sophistication of their methods and techniques. 
Since 1980s, Nigeria has also remained a major trans-shipment point for heroin and cocaine going to south Asia and Latin America respectively; indeed the sophistication of the mafias operation has reached the point that apprehended suspects has been discovered to swallow drugs in wraps with a view to excreting them at destination countries. Lewis (1996) observed that while the country maintained the trade of the protection of top military brass, the syndicates, who had gradually move their operations to third countries, laundered the proceeds from the trade through domestic banking system, in conformity with earlier alluded self-serving principle of "see no evil, hear no evil" (Dauda,2010). Apart from drugs, the circumvention of the formal economic via trafficking of contraband goods has also counted local industries. At a pre-yearly general meeting with the medias in July 2004, Nigeria industrialist under the aegis of the manufacturers association of Nigeria (MAN) declared that the country lost $\$ 6.3$ billion (about N800 billion) to unwholesome trade practises of smuggling and products counterfeiting in 2003(The Guardian, Monday July 5,2004.p. 1 and 4).s

\section{CONCEPTUAL ISSUES ON BORDER SECURITY}

\subsection{What does Border Security Mean?}

Border security is a factor of border management. International borders are a security issue for all governments. States are recognized under international law by their capability to maintain their boundaries, secure their territories, and protect their citizens. The ability to secure national borders is one of the criteria used to classify states as strong, weak and failed. A state has a primary responsibility of protecting its citizens from both internal and external threats to their livelihoods. It must be pointed out that the strategic location of a country determines opportunities for illegal activities that exists or can take place in its border areas. Some countries are more threatened by insecurities or mismanagement of other countries borders than their own. Border Security means different things: border control, border management, border monitoring, border protection, etc. Usually, border security has been used to mean border control, which seeks to facilitate or limit the movements of people, animals, plants, and goods in and out of a country. Border control is divided into two main categories: securing borderlines (activities along the boundary), and controlling ports (harbors, border posts and airports) of entry.

\subsection{How can Border be Managed?}

Border management: commonly defined as the government functions of immigration, customs and excise, and policing, with the aim of controlling and regulating the flow of people and goods across a country's border/boundary in the national interest (particularly economic development, security and peace). Border management also includes maintenance of boundary beacons that mark the physical limits of the country's territory. Border management is a collaborative process between a country and its neighbors. It cannot be done unilaterally, and it is most effective and efficient when done regionally.

Border management has a number of stakeholders:

- Key government agencies (customs, immigration, police, armed forces, ministry of agriculturequarantine purposes), who in most cases operate independently and without networking or exchanging information.

- Airlines

- Shipping companies

- Border local authorities

- International business companies and individuals

- Individuals (residents of the borders or travelers across boundaries e.g. traders, relatives, tourists or terrorists)

The perceptions that a government/state has of external threats/risks determines its responses to border insecurity and the border management system it puts in place. In other words, how a country/state/government manages its borders reflects its fears and comfort.

Indeed, border management is an expression of a statees sovereignty. A state"s failure to manage its borders can undermine its domestic and international legitimacies. The legal status of a state/government depends on how it manages its borders. The Montevideo Convention on the Rights and Duties of States of 1933 identifies 4 criteria for state sovereignty: permanent population; a defined territory; a government; and the capacity to enter relations with other states. In other words, 
- Territoriality is equal to sovereignty

- Citizenship is defined by territory

- Territory is defined by borders

- Borders enable countries to engage in international relations

- Borders define state-citizenship relationship

Transnational crimes: These are crimes that have actual or potential effect across national borders and crimes which are intra-State but which offend fundamental values of the international community (Bonchuk, 2001. The word "transnational" describes crimes that are not only international (that is, crimes that cross borders between countries), but crimes that by their nature involve cross-border transference as an essential part of the criminal activity. Transnational crimes also include crimes that take place in one country, but their consequences significantly affect another country and transit countries may also be involved. Examples of transnational crimes include: human trafficking, people smuggling, smuggling/trafficking of goods (such as arms trafficking and drug trafficking and illegal animal and plant products and other goods prohibited on environmental grounds (e.g. banned ozone depleting substances), sex slavery, terrorism offences, torture and apartheid. Transnational organized crime (TOC) refers specifically to transnational crime carried out by organized crime organizations.

Transnational crimes may also be crimes of customary international law or international crimes when committed in certain circumstances. For example they may in certain situations constitute crimes against humanity. The international community is confronted with an increasing level of transnational crime in which criminal conduct in one country has an impact in another or even several others. Drug trafficking, human trafficking, computer crimes, terrorism, and a host of other crimes can involve actors operating outside the borders of a country which might have a significant interest in stemming the activity in question and prosecuting the perpetrator. Contemporary transnational crimes take advantage of globalization, trade liberalization and exploding new technologies to perpetrate diverse crimes and to move money, goods, services and people instantaneously for purposes of perpetrating violence for political ends. (Dan E. Stigall, 2013)

Moreover, problems of weakened states and transnational crime create an unholy confluence that is uniquely challenging. When a criminal operates outside the territory of an offended state, the offended state might ordinarily appeal to the state from which the criminal is operating to take some sort of action, such as to prosecute the offender domestically or extradite the offender so that he or she may face punishment in the offended state. Nonetheless, in situations in which a government is unable (or unwilling) to cooperate in the arrest or prosecution of a criminal, the offended state has few options for recourse.

\section{CONCEPT OF SECURITY}

Security is the degree of resistance to, or protection from, harm. It applies to any vulnerable and valuable asset, such as a person, dwelling, community, nation, or organization. As noted by the Institute for Security and Open Methodologies (ISECOM) in the OSSTMM security provides "a form of protection where a separation is created between the assets and the threat." These separations are generically called "controls," and sometimes include changes to the asset or the threat.

Abraham Maslow describes an insecure person as a person who "perceives the world as a threatening jungle and most human beings as dangerous and selfish; feels rejected and isolated person, anxious and hostile; is generally pessimistic and unhappy; shows signs of tension and conflict, tends to turn inward; is troubled by guilt-feelings, has one or another disturbance of self-esteem; tends to be neurotic; and is generally selfish and egocentric.

National security is the requirement to maintain the survival of the state through the use of economic power, diplomacy, power projection and political power. The concept developed mostly in the United State after world war 11. Initially focusing on military might, it now encompasses a broad range of facets, all of which impinge on the non military or economic security of the nation and the values espoused by the national society. Accordingly, in order to possess national security, a nation needs to possess economic security, energy security, environmental security, etc. Security threats involve not only conventional foes such as other nation state but also non-state actors such as violent non-state actors, narcotic cartels, multinational corporation and nongovernmental organization; some authorities include natural disaster and events causing severe environmental damage in this category. 


\section{THEORETICAL ISSUES}

It has become a universal phenomenon in social sciences for facts to be investigated or examined precisely within a paradigm, rather than in an isolated manner. For Goode \& Hatt (1952), theoretical orientation functions mainly by bridging the range of facts that are to be investigated. In an empirical theoretical base, it is necessary to develop a sound theory, which is capable of explaining the wise concepts and relationship in the study. The essentiality of theoretical paradigm in a study is also pigeon-holed in the fact that social science research is theory based and its operations are guided by relevant principles of human behavior Functional prerequisite, a theory compounded by Talco Parson, was employed to explain the reason why Nigerians neighbour could not be sustain by their environment as a result of climate change had to engage in trans border crime to survive hardship impinged on them by the variability of climate.

According to Adejuyigbe (2006), functional prerequisite provide an explanation for environmental adaptation, societal goals attainment, integration and the maintenance of pattern. Though it was propounded in the $19^{\text {th }}$ century the theory is still relevant to the explanation of the survival social system in the modern day world. Studies have revealed most of the high way robberies where committed by the herdsmen who are forced to migrate to Nigeria as a result of the effect of climate change in their country. The incessant religious crisis in the country has also been traced back these illegal immigrants-The Fulani herdsmen in particular (Bala-Gbogbo, 2010). In the southern borders of Nigeria, especially near the Seme and Idiroko borders, foreigners from Togo, Mali and Benin Republic capitalize on the Lax borders security to "invade" the country to engage in nefarious activities such as human trafficking, smuggling, car theft etc. The security of the nation is threatened by the activities of these foreigners whose social economic means of survival have been disrupted by climate change with resultant advance impact on food security, sustainable life, fresh water resources, human health and settlement.

\section{NATURE OF BORDER ROUTES IN NIGERIA}

The major border countries with Nigeria are Cameroon (1,690 kilometers) in the east, Niger $(1,497$ kilometers) in the north, Benin (773 kilometers) in the west, and Chad (87 kilometers) in the northeast. Most of these border areas are either mountainous or in the jungle which makes effective surveillance in the borders very difficult (Mustapha, 2004).

In these major borders, there are over hundreds of illegal routes in Nigeria that link or lead to some neighboring African countries. Nigeria's borders are massive with hundreds of footpaths crisscrossing to neighboring countries of Cameroon, Chad and Niger with links to Mali, Libya and Sudan. From conservative estimate by locals, there are well over 250 footpaths from Damaturu/Maiduguri axis that link or lead direct to Cameroon, Chad or Niger. These paths are mostly unknown by security agencies, are unmanned, unprotected and thus serve as leaky routes for arms and ammunitions trafficking in to Nigeria. It is disheartening and unfortunate that the "merchants of death" have since devised methods use to beat security agencies at the borders and through the footpaths. These methods include the use of camels, donkeys and cows to traffic arms, ammunition and drugs, like cocaine into Nigeria. The fact that the weapons are small, light and collapsible makes it easy to be concealed and moved on camels and donkeys' back in a specially crafted skin or thatched bags mainly meant for the illegal "expedition" unexpected, unsuspected and therefore undetected. Similarly, some cows and grains merchants in the North- East sub - region of the country, devices means of hiding cache of arms and ammunition in empty fuel tankers, under vehicles' engines and inside bags of grains mostly undetected by security agencies at the affected border posts. The "grains" are transported in large number via trucks, trailers, Lorries and old model pickup vans and jeeps with little attention given to them by security agents, (Sagir Musa,2010). Further analysis on security challenges can be drawn from the series of report from border criminal activities resulting from the outnumbered illegal route as against the Legal route which lacks adequate management coverage as illustrated below;

Table1. Showing the outnumbered illegal route as against legal route in Nigeria.

\begin{tabular}{|c|c|c|}
\hline Legitimacy & Routes & Activity \\
\hline Legal & $\mathbf{8 4}$ & Majorly importation of goods and services (free market) \\
\hline Illegal & $\mathbf{1 , 9 7 8}$ & $\begin{array}{c}\text { Majorly illegal entry, smuggling of cars, arms Smuggling, exportation of drugs } \\
\text { and Human trafficking. }\end{array}$ \\
\hline
\end{tabular}

Nigerian informal cross-border trade is estimated around 20\% of its GDP and includes trade with all its neighbors, especially Niger and Cameroon. Many of these neighbour countries dependent on the 
openness of the Nigerian (illegal) market. Nigeria has already taken advantage of this in the past by using its border policies to manifest its power. In 2003, when the border between Nigeria and Benin Republic for instance was closed by Obasanjo, the Beninese economy found itself in high distress. A key commodity illegally imported to Benin is petrol. Cheaper in Nigeria, petrol is smuggled into Benin in large quantities. This contraband business is an important source of income for many of the border community members. In $2004,73 \%$ of the Beninese market was satisfied by illegally imported petrol which is more readily available in remote regions and more affordable than the petrol offered by the state-owned stations. For some other commodities, such as agricultural goods, the volume of informal cross-border trade between Nigeria and its neighbors is estimated to be ten times higher than declared at customs. Informal cross-border trade can be seen as a positive or negative phenomenon, depending on the viewpoint taken. On the one hand, it is a manifestation of an ancient solidarity between people that were separated by colonial borders. It can be seen as an expression of entrepreneurship and economic dynamism that is healthy for any economy and which secures the livelihood of many families. On the other hand, custom evasion deprives the state of important revenues which contributes to the weakening of public institutions and the state's legitimacy (Afrika, Jean-Guy K. \& Ajumbo, Gerald, 2012).

Informal trade, both legal and illegal is the most common form of trans-border activity in the region. Less common, but still important is transnational organized crime (TOC), which has been growing in the region over the past few years. Despite increasing sub-regional and international cooperation, criminal cross-border activities remain a key variable of instability in the sub-region. It is only in recent years, that the complexity of TOC has steeply increased. This development has occurred parallel to an increased commitment towards free movement of persons and goods in the ECOWAS region that is designed to stimulate growth and stability in the region.

Table2. Routes through which contraband goods are smuggled into and out of Nigeria

\begin{tabular}{|c|c|c|c|c|}
\hline S/no & $\begin{array}{l}\text { Routes of } \\
\text { smuggling }\end{array}$ & Items smuggled into Nigeria & Items smuggled out of Nigeria & border \\
\hline 1. & $\begin{array}{l}\text { Idiroko } \\
\text { border }\end{array}$ & $\begin{array}{l}\text { Rice, apple, frozen foods, secon d hand } \\
\text { cloths, textile materials, used tyres, } \\
\text { vehicles, vegetable oil, spirit, flours, } \\
\text { arms and ammunitions }\end{array}$ & Petroleum products & Nigeria- Benin \\
\hline 2. & Ilela & $\begin{array}{l}\text { Wheat, flour, sugar, confectiona ries, } \\
\text { spaghetti/noodles, used vehicles, } \\
\text { textiles, foot wears etc. }\end{array}$ & $\begin{array}{l}\text { Millets, maize, petroleum } \\
\text { products, fresh fruits, cement }\end{array}$ & $\begin{array}{l}\text { Nigeria-Niger } \\
\text { (sokoto) }\end{array}$ \\
\hline 3. & Jibia & $\begin{array}{l}\text { Rice, palm oil, spaghetti, macaroni, } \\
\text { used vehicles and tyres }\end{array}$ & $\begin{array}{l}\text { Cement, petroleum products, } \\
\text { woods and furniture, groundnut } \\
\text { oil, beans, yam, sugar, corn. }\end{array}$ & $\begin{array}{l}\text { Nigeria-Niger } \\
\text { (kastina) }\end{array}$ \\
\hline 4. & Mfum & $\begin{array}{l}\text { The presence of the military at the } \\
\text { Bakassi Pennisula has temporary led to } \\
\text { diversion of smuggling from this area. }\end{array}$ & & $\begin{array}{l}\text { Nigeria- } \\
\text { Cameroon border } \\
\text { (Cross river) }\end{array}$ \\
\hline 5. & Bele sahoda & & Petroleum product & $\begin{array}{l}\text { Nigeria Camer- } \\
\text { oon border } \\
\text { (Adamawa) }\end{array}$ \\
\hline 6. & $\begin{array}{l}\text { Gamboru- } \\
\text { Ngala }\end{array}$ & $\begin{array}{l}\text { Arms and ammunitions, rice, textile, } \\
\text { beverages, used vehicles. }\end{array}$ & $\begin{array}{l}\text { Petroleum product, grains, } \\
\text { drugs/Indian hemp. }\end{array}$ & $\begin{array}{l}\text { Nigeria-Niger } \\
\text { (Borno) }\end{array}$ \\
\hline 7. & Seme & $\begin{array}{l}\text { Arms and ammunitions, used vehicles } \\
\text { and parts, rice, textile and frozen food } \\
\text { (turkey, chicken and fish). }\end{array}$ & Petroleum products & $\begin{array}{ll}\text { Nigeria- } & \text { Benin } \\
\text { (lagos) } & \end{array}$ \\
\hline 8. & $\begin{array}{l}\text { Coastal } \\
\text { area }\end{array}$ & $\begin{array}{l}\text { Textiles, arms and ammunitions and } \\
\text { human trafficking. }\end{array}$ & $\begin{array}{l}\text { With the withdrawal of } \\
\text { subsidies in petroleum products, } \\
\text { land smuggling in this product } \\
\text { has reduced. However, it is still } \\
\text { lucrative through the creeks to } \\
\text { other African countries. }\end{array}$ & $\begin{array}{l}\text { Linkin up Cote- } \\
\text { d'ivoire, Benin, } \\
\text { Equatorial, } \\
\text { Guinea, and } \\
\text { Central Africa. }\end{array}$ \\
\hline
\end{tabular}

Source: Human Rights Watch (2003). The Warri Crisis: Fueling Violence. Lagos Human Rights Watch. Retrieved from http://www.hrw.org/sites/default/files/reports/nigerial103.pdf. 
Despite long-standing ECOWAS plans for a customs union, little progress has been made, largely because of Nigeria's unwillingness to participate. It has maintained one of the most protectionist trade policies in the world, with very high tariff spikes and a large number of import bans. Unlike Benin and Togo, Nigeria has relatively developed but often inefficient manufacturing and agricultural industries, with powerful interest groups favouring protection.

The highly discretionary application of policies is also notorious. Recently, some progress has been registered in ECOWAS's efforts to liberalise, with Nigeria participating in negotiations (World Bank 2009). Nigeria had insisted on a fifth tariff band of 50 per cent. Whether or not agreement will be reached and if so, how many products will be included in the fifth band and the extent of Nigerian implementation will be crucial for the future of Togo's and Benin's transit re-export trade. In October 2008, Nigeria removed 25 products from its list of prohibited imports, including some meat products, flowers, cassava, fresh and dried fruits, wheat, cocoa butter, biscuits, beer, some truck tyres, selected textile products, and bicycle frames. In many cases, it eliminated import bans that had been introduced in the last few years, returning the situation to roughly what it was in 2004. The most important remained in place, however, including frozen poultry, textiles, clothing, footwear and used cars, although the allowed age used car imports was extended from 8 to 10 years. In 2017, a new regulation have been made to domesticate all vehicles to custom clearance, which means that all incoming vehicles must pass through legal means and must have all the necessary documents for clearance. For a number of other important goods such as rice, cigarettes and sugar, high tariffs remain.

\section{Border Management AND SECurity Challenges in Nigeria}

Border security is a factor of border management. International borders are a security issue for all governments. Border security and the management of borders in ways that promotes national security has generally been given low priority in Africa and Nigeria in particular compared to security provided for political elites and their assets in the national capitals and other urban areas far-removed from the borders. While national security strategies of the country are left to be suffered. The negligence of border security and poor, border management in Nigeria has largely contributed to a prevalence of threats such as cross-border crimes; Nigeria border security issues are distinctive, when compared to the other countries of the world. Because of this fact, these borders are not monitored, patrolled or controlled. Consequently, these borders have become transit points for smuggling and other illegal cross-border activities Guy Martin, (2011). In other words, most, if not all the borders in Nigeria is transnational crime zones. The conundrum of national security in Nigeria has been compounded by the porous nature of Nigerian borders. When borders cease to function effectively, different forms of crimes prevail and the security of a state or region is put in serious jeopardy because borders constitute the most visible sign of the sovereignty of a State on its territory. Border management is therefore crucial to a State's involvement in the protection of its population against what it considers as threats ranging from migration, international terrorism, and multiform trafficking as in human beings, drug, raw materials or SALW (Jihan \&Cédric, 2010). Interestingly, Nigeria's border points especially in the North-east and North-west no longer perform their strategic functions but serve as channels for smuggling of all sorts of illicit materials into the country. The current security challenges in Nigeria where the nation's Northern borders with Niger and Chad witness the unrestrained incursion of armed bandits to terrorize innocent citizens in towns and villages on the Nigerian side of the border calls for the need to put in place a rather effective border control system (Makka, 1989)

Key issues in border management in Nigeria are:

1. Human Trafficking: The trafficking of children for the purpose of prostitution and form of exploitative labour is a widespread issue in Nigeria. Foreign children trafficked to Nigeria come mainly from Benin and Togo (an estimated $96 \%$, with $90 \%$ of that figure coming from Benin alone), Cote d'Ivoire and Niger. Children as young as five and six years trafficked from Benin have been found working in exploitive conditions in Nigeria mines in the Western part of the country. Trafficked girls are used for domestic services or street trading as well as commercial sexual exploitation while boys are generally forced to work on plantations or in commercial farming, construction, quarries and mines or engaged in petty crimes and drug trade (UNDOC, 2006). With respect to women trafficked to Europe for the purpose of sexual exploitation, an estimated $94 \%$ are from Edo State while the remaining are from Delta, Kano and Borno State.

2. Arms Smuggling: Over70\% of about eight to 10 million illegal weapons in West Africa is in Nigeria. The high rate of illegal procurement and use of SALWs in Nigeria is indexed by the intermittent seizure of SALWs by security and border control officers, the frequency of deployment 
of these arms in conflict and crime scenes, and the level of human casualty and material damage recorded in the aftermath of its use in the country. For instance, the quantity of arms surrendered during the disarmament and demobilization (DD) phase of the Amnesty programme for the Niger Delta militants in 2009 gave an idea of the quantum of SALWs proliferation in the country. The Amnesty initiative saw over 15000 militants surrender arms at the expiration of the DD phase of the Amnesty. Weapons recovered during the disarmament process included 2760 assorted guns, 287445 ammunitions of different calibre, 18 gun-boats, 763 dynamite sticks, 1090 dynamite caps, 3155 magazines and several other military accessories, such as dynamite cables, bulletproof jackets and jackknives. It is widely believed that militants only surrendered a small fraction of their arms, as most of them doubted the government's genuine commitment to the amnesty. The regular interception of illegal arms trafficking within and across the borders by security agencies also reveals the worrisome dimension that arms proliferation has recently assumed in the country. (Bestman Wellington, 2006.)

3. Drug Trafficking: Drug trafficking has become a common phenomenon among West African countries like Nigeria, the Gambia, Ghana, Niger and Burkina Faso. The reason is not far-fetched. Profits from drugs and guns reportedly exceed that of human trafficking. The United Nations Office on Drugs and Crime alarmingly revealed that the volume of cocaine transiting the West African region is roughly 50 tons annually (United Nations, 2008).

The commonly trafficked drugs include heroine, cannabis, cocaine and synthetic drugs. The drug menace became one of Nigeria's major security challenges right at the dawn of independence with discoveries of cannabis farms in the country, arrests of Nigerian cannabis traffickers abroad, and reports of psychological disorders suspected to be associated with cannabis use. In the early 1980s however the problem of drug trafficking became a major problem following alleged involvement of military personnel in heroin trafficking in Nigeria (Obot, 2004). Nigeria is a major source of heroin and cocaine. Nigerian drug dealers use large numbers of small-scale smugglers, each carrying a tiny quantity of heroin, sometimes packed in condoms and then swallowed. The major routes of Nigerian traffickers are Ghana, the Ivory Coast, Senegal and South Africa for heroin and cocaine destined for Europe and the United States (Sabrina et al., 1998). Nigeria and Senegal are the source of the greatest volumes of cocaine seized on commercial air flights (United Nations, 2008). The menace of drug trafficking in and out of the country had necessitated the enactment of several drug law and policies. Drug abuse has become prevalent in the country amid the daunting security challenges. The drugs come into the country as a result of the porous borders and poor security in the airports. According official figures from the National Drug Law Enforcement Agency (NDLEA), 37\% of Kano State's population is drug abusers and the state also has the highest number of people arrested for illicit drug trafficking (Ogene, 2013).

4. Smuggling of Contrabands: (untaxed cigarettes and alcohol) is a common occurrence over most borders. The smuggling of contraband goods and undocumented aliens is usually done with the connivance of border personnel (customs \& immigration). Auto theft-in Nigeria, is also a serious matter mostly along Benin Republic is on a high side to the level that over 100 vehicles are usually stolen in Nigeria per month to neighboring countries, mainly Land Cruisers, four wheel drives, Mercedes-Benz, Toyota and BMWs. The criminals steal and smuggled these vehicles across the borders with Nigeria each month. This is done with the assistance of border communities who "hide the vehicles and provide information on local law enforcement patrols" for a fee of between $\$ 150$ 200 and Naira as the case may be.

\section{SOURCES OF NIGERIA BORDER INSECURITY}

- Lack of political will and commitment of resources to effectively manage borders.

- Lack of cooperation within departments, between departments and between countries.

- Inadequate personnel available for deployment on the borders.

- Inadequate skills of personnel deployed to manage borders.

- Poor motivation among border personnel.

- Lack or poor intelligence sharing between agencies and countries.

- Lack of facilities and equipment to secure and manage borders.

- Lack of office spaces \& accommodation for border patrol \& control personnel (dilapidated houses with collapsing walls and leaking roofs). 
- Poor and inadequate communication channels-most of the border management personnel do not have the basic communication means such as radios or even mobile phones.

- Lack of transport and roads along borders to enable patrols.

- Poorly controlled and managed border points due to absence of offices.

- Poorly demarcated borders; as pointed out above, more than $75 \%$ of African boundaries are poorly marked or unmarked.

- Illegal border crossing points, usually called "mice or rat routes," are used by smugglers who charge a fee ranging from \$15-100 depending on the difficulty of terrain and presence of border security personnel.

- Porosity of borders: "The porosity of the land borders is perceived by some as a danger and vulnerability, but for the borderland communities it is an essential part of their very mode of transnational existence, of their social and economic life and of the cultural uniqueness that conform to their identity and livelihoods.

- Presence of cross-border communities that are difficult to administer and often uncooperative in managing borders. Some borders, particularly in Eastern African, have become almost unmanageable due to the lifestyles (gun culture) of pastoralist border communities.

- Lack or non-functioning border commissions.

- High-level corruption, most of the border security in Nigeria and environ are highly corrupt. Many of the security officers have been accused, such as immigration officials of selling passports to foreigners and police of fleecing passengers at checkpoints.

\section{CONCLUSION AND RECOMMENDATIONS}

Cross-border crimes contribute significantly to the destabilization of political, economic and social activities in the ECOWAS sub-region. Transnational criminal activities in West Africa are rather one of the symptoms of larger underlying structural problems than the cause of insecurity. Over the years, Nigeria has initiated measures to check firearm proliferation. The Firearms Act of 1959 (amended) spelt out prohibitions on use, exemptions, licensing before possession, manufacture and sales of firearms, including punishment for offenders. There are also laws against robbery and use of firearms for the same purpose as well as committees to check proliferations. Regional coordination has improved in many areas. For examples, regarding small arms (Convention on small arms and light weapons, their ammunition and related materials, June 2006), human trafficking (Plan of action and declaration) and narcotics (the newly established ECOWAS Drug Control Unit). It has also focused on terrorism, under the auspices of ECOWAS, with the recent adoption of the regional Counter Terrorism Strategy and Implementation Plan. However, it results from the absence of significant improvement of these problems that "...the underlying factors contributing to the outbreak of these crimes as well as the complex linkages between them" have not yet been sufficiently addressed. This is necessary to achieve significant improvement of these problems. Nigeria's borders are "very porous" and the current 20,000 customs personnel in the country are inadequate to police them.

Realizing the dangers posed by such cross-border security issues, the United Nation Security Council called on states in West African sub-region to take a number of measures to address issues of bordercrimes and security. This was a report of 12 march, 2004 on West Africa and its recommendations to address cross-border issues with a regional context and in coordinating manner. This paper therefore focused on the blue-print recommendations of ECOWAS and other alternative options to address cross-border crime and security in West Africa sub- region. some effort have been made to prevent, control and possibly eradicate cross-border crime activities in west Africa but these effort have not succeeded in reducing the on-going cross-border crimes. The on-going cases of small arms, drugs and human trafficking as well as smuggling of cars and other goods, call for more effective responses to the different categories of crime. In the light of this, the various international, regional and subregional legislation on the different crimes categories needs to be revisited and measures put in place to disseminate them towards their effective implementation. Programs should be undertaken by both security agencies and relevant NGOs on the impact of legislation within the various ECOWAS member state. There is a need to introduce community policing at the local or grassroots level in order to collaborate, share information on cross-border crimes and criminality. To this end, advocacy for greater involvement of the civil society needs to be stepped up. Civil Society Organizations have proven very indispensible in the security sector, especially in the areas of sensitization of the public on 
the dangers of crime and providing necessary information to security agencies. Also, given the limits on the exercise of extraterritorial enforcement jurisdiction, states have developed mechanisms to cooperate in transnational criminal matters extradition measure. Extradition is the mechanism by which one sovereign request and obtains custody of a fugitive located within the jurisdiction and control of another sovereign Through the extradition process, a sovereign (the requesting state) typically makes a formal request to another sovereign (the requested state). If the fugitive is found within the territory of the requested state, then the requested state may arrest the fugitive and subject him or her to its extradition process. The extradition procedures to which the fugitive will be subjected are dependent on the law and practice of the requested state.

\section{REFERENCES}

[1] Adejuyigbe, O. (2006). Identification and Characteristics of Borderlands in Africa. In:

Asiwaju, A. I. and Adeniyi, P. O. (ed.), Borderlands in Africa. A Multidisciplinary and Comparative Focus on Nigeria and West Africa, University of Lagos Press, Lagos.

Afrika, J. K. and Ajumbo, G.(2012). "Informal Cross Border Trade in Africa: Implications and Policy Recommendations", African Economic Brief,

AfDB, Vol. 3 No. 10, November, p. 8.

[2] Bhagwati, J. and B. Hansen (1973), 'A Theoretical Analysis of Smuggling', Quarterly Journal of Economics, 87(2), 172-87.

[3] Bala-Gbogbo , E. (2009). Climate Change Effects Mount in Nigeria Department for International Development (DFID) 2009, Fighting Climate Change and poverty, 46.www.development.org.uk [05.12.2011]

[4] Bayard .J,F,Ellis nd B.Hibou,(1999),'” from Kleptocracy to the Felonious state?' In Bayard, et al (eds.), the criminalizing of the state in Africa, Oxford and Indiana.

A.I Asiweju . 'border and national defence A .E Ekoko; M. A. VOGT. Nigerian

Defence policy issues and problem'.

[5] Bestman W, (2006) "Weapons of War in the Niger Delta" IIRIN, May 2006, quoted in Bestman Wellington's article, "Weapons of war in The Niger Delta"

[6] Bestman, W. (2007) "Weapons of war in the Niger Delta" an article published by the Jamestown Foundation, Terrorism Monitor, New York. USA.

[7] Binder, D. (2004). The Dimensions of Organized Crime in the Bulkans (Paper presented at the Forum on Trafficking of Humans and Human Organs organized by the Center for European and Eurasian Studies and the Burkle Center for International Relations on May 14).

[8] Bonchuk, M. O. (2001). The Challenge of Parallel Administration in a Bifurcated Borderland: Focus on the Cross River "Gateway Way" Local Government Areas with South West Cameroon, Institute for Public Policy and Administration, University of Calabar. Boister, N. (2003). "Transnational Criminal Law?". European Journal of International Law 14: 953, 967-77. Notre Dame Journal of International Comparative Law 3(1). Retrieved 2013- Dan E. S, Dauda, S.G (2010). Trans-Border Economic Crime, Illegal Oil Bunkering and Economic Reforms in Nigeria,Policy Brief Series, No. 15,octber 2010.

[9] Gilmore, W.C. (1999). Dirty Money, Council of Europe Publishing.

[10] Goode, W. and Hatt, P. (1952): Methods in social Research, Singapore, McGraw Hill Book Company Inc

[11] Hughes, D. (2004). Sex Trafficking in Ukraine and Russian: Violence. Corruption, and state Policy (Paper presented at the Forum on Trafficking of Humans and Human Organs organized by the Center for European and Eurasian Studies and the Burkle Center for International Relations on May 14).

[12] Human Rights News (2006). "Soldiers, Police Seize High Caliber Riffles in Rivers," (Vol. 1. No.1. October, 2006 edition), a publication of the Centre for Environment, Human Rights and Development (CEHRD), Ogale-Nchia Eleme, Rivers State, Nigeria.

[13] Human Rights Watch (2003). The Warri Crisis: Fueling violence. Lagos: Human Rights Watch. Retrieved from htt://www.hrw.org/sites/default/files/reports/nigeria1103.pdf. 
[14] Jihan S. \& Cédric P. (2010) Managing Land Borders and the Trafficking of Small Arms and Light Weapons, Groupe de richer cheated' information Kligman. G. (2004). Trafficking Women to through and from Eastern (Paper presented at the Forum on Trafficking of Human Organize by the Center for European and Eurasian Studies and the Burkle Center for International Relation on May 14th.

[15] Lewis. P. (1996). From Prebendalism to Predation: The Political Economy of Decline in Nigeria. The Journal of Modern African Studies, 34(1), pp. 79-103.

[16] Luna D.M (2008). Dismantling Illicit Networks and Corruption Nodes. From http://www. 13iacc.org/IACC workshop 6.2. (Retrieved March 8, 2010).

[17] Makka, F. Lt. Col. Rtd (1989), Nigeria - Cameroon Border: Memorandum by Benue State in Asiwaju, A. I. (ed.) Development of Border Regions.

[18] Maslow, A. H. (1942). "The Dynamics of Psychological Security-Insecurity". Journal of Personality 10 (4): 331-344. doi:10.1111/j.1467-6494.1942.tb01911.x.

[19] Mustapha, M. (2004). Globalization and Trans-border Crime: Nigeria's Security Delimma, Retrieved from www.gamji.com/NEWS2809.htm.

[20] Obiagwu, K (2002), Independence Day and Ironies of Greatness. The Guardian (Lagos)

[21] Obot I. S. (2004) “Assessing Nigeria's drug control policy, 1994-2000,” International Journal of Drug Policy 15 (2004) p. 17-26

[22] Ogene A. (2013) 'Drug and Poverty Blight Northern Nigeria,' Aljazeera available at http://www.aljazeera.com/indepth/features/2013/drug-poverty-blight-northern-nigeria201312984336715637.html

[23] Opara, S, (2010), Nigeria loses $\$ 7.7 \mathrm{~m}$ daily oil theft. The punch (Lagos), retrieved from http://www.punchng.com/Articl.aspx?theartic

[24] Ortuno M.T, Apiwan, W (2009). Cooperation and Shared responsibility in the Global Fight Against Organism crime in Particular Drug Trafficking, Illegal Arms Sales, Human Trafficking and Cross-Borded Terrorism. DRAFTREPORT submitted to IDI Assembly of the Interparliamentary Union and Related Meetings, General.

[25] Sabrina et al. (1998) Organized Crime Around The World. European Institute for Crime Prevention and Control, affiliated with the United Nations (HEUNI) Publication Series No. 31. Helsinki, Finland

[26] Sagir, M. (2010)Border Security, Arms Proliferation and Terrorism in Nigeria; a working paperSee Guy Martin, "Illegal Migration and the Impact of Cross Border Crime." Web link: http://www.defenceweb.co.za/index.php?option=com_content\&view=article\&id=14001:featureillegal-migration-and-the-impact-of-cross-border-crime \&catid=87:border-security\&Itemid $=188$, 9 March 2011.

[27] United Nations (2008) 'Drug Trafficking As a Security Threat in West Africa,' the United Nations Office on Drugs and Crime, November 2008 U.S. Department of Justice (2013). "Ungoverned Spaces, Transnational Crime, and the Prohibition on Extraterritorial Enforcement Jurisdiction in International Law"06-11.

[28] Williams,P (1998), ''trans-borded criminal organizations and international security in Michael T.Klare and Yogessh (eds.)World Security Challenges for the New Century, St .Martin's press, New York.

Citation: Osimen, Goddy U et al. "The Borderless-Border and Internal Security Challenges in Nigeria." International Journal of Political Science (IJPS), vol 3, no. 3, 2017, pp. 17-27. doi: http://dx.doi.org/10.20431/2454-9452.0303003.

Copyright: () 2017 Authors. This is an open-access article distributed under the terms of the Creative Commons Attribution License, which permits unrestricted use, distribution, and reproduction in any medium, provided the original author and source are credited. 